\title{
THE DEVELOPMENT OF A STAKEHOLDER-BASED SCALE FOR MEASURING CORPORATE SOCIAL RESPONSIBILITY IN THE BANKING INDUSTRY
}

\begin{abstract}
Research on Corporate Social Responsibility (CSR) has notably increased in recent years and many scales for measuring CSR image have been developed in academic literature. Due to the contextual character recognized in the implementation of CSR strategies, in this paper a new scale based on stakeholder theory is developed to evaluate customers' perception regarding the CSR performance of their banking service providers. The proposal of reliable measurement tools for evaluating customers' perception is especially relevant for companies because of their significant role in influencing the design and implementation of corporate strategies. Results demonstrate the reliability and validity of this new scale in two different samples. In the banking industry, CSR includes corporate responsibilities towards customers, shareholders, employees, society and all legal and ethical requirements of banking institutions. Nevertheless, different kinds of banking institutions have specific CSR images, which reveal different strategic approaches to CSR.
\end{abstract}

\section{Keywords:}

Corporate Social Responsibility; corporate image; scale development; banking industry. 


\section{Introduction}

Since the beginning of the financial crisis in 2008 an increasing attention has been devoted to Corporate Social Responsibility (CSR), that is, the "company activities demonstrating the inclusion of social and environmental concerns in business operations, and in interactions with stakeholders, also according to the ambition levels of corporate sustainability" (van Marrewijk 2003). CSR is now considered essential for the recovery of corporate credibility and customers' trust so companies increase their social investment in order to reestablish their reputation (Piñeiro et al. 2009). Other significant reasons behind this interest also include the improvement of employees' motivation, the desire to be perceived as an innovative organization or the establishment of beneficial relationships with stakeholders (Server and Capó 2009).

Taking these ideas into account, then, studying stakeholders' perception is essential when evaluating the success of corporate CSR policies. Among stakeholders, special attention has been given to the study of customers (Selvi et al. 2010) since their expectations and opinions are considered to directly influence the design of corporate strategies. Thus, the study of CSR image as perceived by customers is crucial for corporate evaluation and is the main purpose of this paper. However, when analysing tools proposed in academic literature to measure CSR image some significant limitations are observed which justify the proposal of a new scale in our research.

First, most authors have conceived CSR image on a limited basis, defining it as the perception of only ethical or philanthropic corporate responsibilities. As a result, a large number of studies can be found that have proposed to gather customers' CSR image through one-dimensional measurement scales (Lichtenstein et al. 2004; Podnar and Golob 2007; Marín and Ruiz 2007). Nevertheless, it is well known that customers, at the time of forming an image of the business, use all the information available of its features and activities. So, corporate relationships with other stakeholders beyond society are underrepresented in one-dimensional scales.

CSR is more commonly measured using multidimensional tools (Maignan et al. 1999; Maignan 2001; Mercer 2003; Decker 2004; García de los Salmones et al. 2005; Kim 
and Choi 2007). This perspective more clearly reflects the numerous theoretical dimensions that are considered in CSR. However, the multidimensional approach is not without critics. In this sense, those studies which adopt this perspective are based on different theories and social approaches to define the dimensions that compose CSR image, thus contributing to the evident lack of consensus (Turker 2009). Some examples are scales based on Carroll's proposal (1979), the sustainable development theory (van Marrewijk 2003) or the stakeholder theory (Clarkson 1995; Mercer 2003; Decker 2004; Turker 2009).

Furthermore, it has been demonstrated that CSR does not mean the same thing in every industry as it does not mean the same for all stakeholders (Decker 2004). Thus, multidimensional scales, which are generally intended to be applicable to any context, are not appropriate as decision tools for managers. As CSR conceptualization differs in diverse industries, more specific tools are needed to measure customers' perceptions regarding this concept.

As an example, the banking industry is a crucial sector in today's economy which deserves further study regarding CSR. The relevance of its analysis in this paper derives from two facts. First, financial institutions are among the most proactive ones investing in CSR (Truscott et al. 2009) while many companies in other sectors only react to the pressure of public opinion (Decker 2004). This involvement in CSR might be directly linked to the fact that the banking industry has traditionally faced tough scrutiny and it has always had to make big efforts to maintain corporate credibility and customers' trust. As a positive CSR image is considered to enhance corporate reputation, it makes sense that banking institutions always rank high on international CSR investment rankings.

Iit is also worth noting that, despite the relevance of CSR in this industry along with the interest of the sector itself in the current financial crisis, a lack of empirical studies regarding CSR and banking institutions still persists in academic literature. In this matter, the authors observed that no studies analysing the measurement of CSR image in the banking industry have yet been published in indexed journals so managers are still in need of high-quality literature to assist them in taking corporate decisions. In order to fill this gap, the authors of this paper have chosen to analyse the Spanish 
banking industry as an interesting case study which could provide useful insights for the study of CSR in a European context.

All in all, the authors propose studying CSR image from a broader perspective than the one used by most researchers in marketing. In doing so, stakeholder theory is considered, as has been proposed in recent studies on CSR (Clarkson 1995; Mitchell et al 1997; Mercer 2003; Decker 2004; Turker 2009). Nevertheless, as pointed out by Mercer (2003), most studies focusing on this issue are theoretical in nature, thus allowing academics and practitioners to understand the normative definition of CSR. However, research on the specific perceptions and opinions of corporate stakeholders has been scarce so far. In order to provide further insight into this topic, in this paper a new measurement scale, solid and reliable, is developed to evaluate the CSR image of banking service institutions from the point of view of their customers.

For this purpose, the paper starts by presenting the situation of the Spanish banking industry as an interesting example for the study of CSR in Europe. In the third section, the diverse academic proposals for the analysis of CSR image in marketing are discussed. Furthermore, the development of the measurement scale proposed in this paper is presented. Then, an analysis of the most significant empirical results is included. Finally, we conclude with a discussion of the most relevant insights provided by the research.

\section{CSR in the banking industry}

The banking sector has experienced an important transformation in recent years due to the important changes that have befallen global markets (Poolthong and Mandhachitara 2009). Globalisation, deregulation, de-intermediation, financial innovation and the appearance of new technologies that modify the traditional distribution channels of banking services (Flavián et al. 2005) have caused the growing homogenisation of institutions. As a result, customers do not currently perceive substantial differences among the institutions and the products and banking services they offer (Mandell et al. 1981). All this is compounded by the international business climate during the last decade, marked by frequent financial scandals and questionable accounting and 
management practices (Piñeiro et al. 2009) leading to the economic crisis of world markets. The result is a loss of society's confidence in the financial system and the institutions that operate in this sector and an increase in the social conscience of regulators, shareholders, employees and customers, who demand better tools for the evaluation of business practices (KPMG 2008).

In this context, it is of vital importance for banking institutions to manage their corporate image to stand out from competitors and to regain customers' confidence in the efficiency of their business (Flavián et al. 2005). Thus, Mandell et al. (1981) point to the importance of managing the sector's image, especially due to such characteristics as the intangibility of the products, the decreasing contact with customers and the need to inspire trust among stakeholders. The aforementioned image must also be managed by taking all its different components into consideration. Corporate image has a multidimensional nature and also covers CSR (Rugimbana et al. 2008). In this sense, Rugimbana et al. (2008) consider that "banks may need to adopt a strategy of maintaining a well-calculated balance between the social and economic aspects of their services to satisfy the needs of banking clients".

CSR management is one of the most recent tools used to improve corporate image (Poolthong and Mandhachitara 2009). Consequently, the banking industry is one of the most proactive investors in CSR (Truscott et al. 2009). In the international realm, for example, there has been a general adoption of CSR principles along with a growing investment in social actions. Furthermore, banking institutions have traditionally been the most linked to the United Nations Global Compact, representing $9.48 \%$ of a total of 3700 subscribing businesses in 2008 (CECA 2008). Similarly, banking institutions are also present in the main sustainability indexes, accounting for more than $11 \%$ of the businesses of FTSE4Good and nearly $22 \%$ of the businesses of the Dow Jones Sustainability Index (CECA 2008).

In Spain, the retail banking sector has also developed multiple social programs in recent years (Abad 2002; Marín and Ruiz 2007), and some of its banking institutions are among the first organisations by investment volume in social actions worldwide. Thus, La Caixa, Caja Madrid and the Santander Foundation are on the list of the 20 largest organisations by investment volume in social actions, with a total of 871.5 million 
Euros invested in 2008. In addition, most of the sustainability reports in Spain are published in the banking sector (19 in 2008), with $84 \%$ of the institutions publishing this kind of report annually (KPMG 2008). The implication of Spanish banking institutions in CSR initiatives along with the frequent communication of these activities make this industry a perfect context for the study of customers' CSR perception.

It is also important to highlight the existence of different kinds of Spanish banking institutions with different approaches to CSR. Building societies and banks are especially relevant since they account for the highest market share. First, building societies have been traditionally linked to CSR, channelled through their foundations and voluntary financing of social projects (Ruiz et al. 2009; Carnero et al. 2010). In this regard, CSR has become a differential trait of building societies which has always been integrated in their corporate mission (Peñas 2011). The profit maximization of these institutions is not devoted to shareholders or investors but to financing social projects so they can comply with social goals such as charity, quality of life, culture, equity and justice (Carnero et al. 2010; Peñas 2011). On the contrary, banks' investment in CSR activities is an answer to the great pressure they have suffered from society because of their greater economic impact. These institutions have been involved in accounting and financial scandals which have led them to think of CSR as a source of competitive advantage. In thinking so, national banks have tried to connect their CSR policies with their corporate strategic management by investing in activities oriented to the enhancement of key stakeholders' benefits (Pérez and Rodríguez del Bosque 2011). These groups are basically primary stakeholders such as customers and employees. Taking these differences into consideration, then, it seems possible that customers' perception of CSR in the banking industry differs, so the evaluation of the new scale should be undertaken for both kinds of institutions.

According to all these ideas, it comes as no surprise that the academic sphere has traditionally been especially interested in the study of CSR in the banking sector. Recent works in Spain, for example, include the papers of de la Cuesta et al. (2006), Pérez and Rodríguez del Bosque (2001) and Bravo et al. (2011), published in the Journal of Business Ethics. However, all these authors focus on analyzing the development stage of internal CSR issues such as social performance, corporate identity or on-line communication. Nevertheless, when it comes to the proposal of measurement 
tools to analyze CSR image in this context, a gap in literature is revealed, which must be filled. Furthermore, scales have been proposed for the measurement of CSR image in the automotive industry or the retail sector, for example. However, no indexed journal has yet published anything related to the banking industry. Therefore, further analysis is advisable.

\section{Academic proposals for the measurement of CSR image}

The strong development of academic research on the CSR concept has also led to the proposal of different strategies to address its study. Measuring CSR has been the goal of many researchers since the emergence of the CSR concept. Focusing on the specific marketing perspective that deals with the study of customers, some authors have proposed to consider CSR image as a unidimensional concept (Lichtenstein et al. 2004; Marín and Ruiz 2007), although it is most commonly considered to be multidimensional (Maignan et al. 1999; Maignan 2001; Mercer 2003; Decker 2004; Podnar and Golob 2007; Kim and Choi 2007).

The most widely supported multidimensional approach was proposed by Carroll (1979) and has later been used by several authors at both a theoretical (Wartick and Cochran 1985; Wood 1991; Schwartz and Carroll 2003) and an empirical level (Maignan et al. 1999; Maignan 2001; García de los Salmones et al. 2005). This author proposes that an exhaustive CSR definition should include corporate economic, legal, ethical and philanthropic initiatives. Obligations within the economic domain include, for example, profit maximization for shareholders, obtaining best value for money, the establishment of a strong competitive position or maintaining a high level of operating efficiency. The legal category is defined by the rule of law (Carroll 1979). The ethical dimension covers corporate activities which are expected by society but not codified in legal codes (Schwartz and Carroll 2003). Finally, the philanthropic dimension poses a set of voluntary actions that go beyond the purely ethical, such as donations to charitable causes, active participation in environmental conservation or sponsorship of cultural activities (Carroll 1979). Taking this theoretical proposition as a reference, several authors have empirically proposed measurement scales for CSR image that try to determine this variable from a stakeholder point of view. Along this line, authors such 
as Aupperle et al. (1985) -financial performance- or Maignan (2001), García de los Salmones et al. (2005) and Podnar and Golob (2007) -customer behaviour- have developed scales to analyze CSR image in different companies and sectors.

However, this model is not without its critics and there are papers that have either failed to demonstrate this dimensioning (García de los Salmones et al. 2005) or have pointed out its limitations (Schwartz and Carroll 2003). Carroll (1979) assumes that the various facets of the concept are closely linked and that, in many cases, they even overlap. For example, the economic dimension encompasses those corporate activities which are aimed at achieving a direct or indirect positive effect on the company, including actions aimed at maximizing profits or corporate value for the stakeholders (Schwartz and Carroll 2003). Taking this last goal into account, any activity included in the CSR concept is economic in nature and falls into the first dimension proposed by Carroll. This perspective would negate the value of distinguishing different dimensions of CSR. Furthermore, in a subsequent revision of the model, Schwartz and Carroll (2003) suggest that philanthropic activities can be subject to both economic and ethical criteria, so that this cannot be considered an independent dimension. These authors reduce the categorization to only three dimensions -economic, legal and ethical responsibilities-. Finally, García de los Salmones et al. (2005) empirically merge ethical and legal dimensions, while Podnar and Golob (2007) also join ethical and philanthropic CSR initiatives.

A second perspective to explain a possible dimensioning of CSR image is the one proposed by the sustainable development approach (van Marrewijk 2003; Panapanaan et al. 2003; Panwar et al. 2006). CSR, found in the "triple bottom line" of the organization, covers the full range of business concerns related to the environmental, economic and social dimensions of companies. However, the special relevance that the environmental dimension holds in this perspective makes its use more focused on the study of those industries that have a special impact on the physical surroundings of the companies, such as tourism (Jamrozy 2007; Timur and Getz 2009) or the forestry and agricultural sectors (Panwar et al. 2006).

To solve the problems posed by the different theoretical perspectives, a more modern approach to explain the components of CSR comes from stakeholder theory (Freeman 
1984), suggesting a dimensioning of the concept according to the main target groups of the organization. In this line, Clarkson (1995) considers that businesses and practitioners manage relationships with stakeholders instead of society as a general concept so we had better address stakeholders' concerns instead of social ones. According to this proposal, CSR activities should preferably be classified as a function of those stakeholders that are most benefited by the actions. They are the main target audiences of the CSR actions, and are thus the ones that businesses want to please. Applying this reasoning, literature has identified several CSR dimensions: customers (Mercer 2003; Decker 2004), employees (Mercer 2003; Decker 2004), shareholders (Mercer 2003), society (Mercer 2003), the environment (Decker 2004), the market (Decker 2004) and a general dimension including all legal and ethical responsibilities of corporations (Maignan et al. 1999). In the analysis of customers' perceptions the studies of Maignan et al. (1999) and Mercer (2003) stand out as they show how customers correctly understand these CSR dimensions, applying them in their evaluations of corporate actions.

\section{TABLE 1}

Dimensional perspectives on the study of CSR image

\begin{tabular}{|c|c|c|}
\hline Perspective & Dimensions & References \\
\hline $\begin{array}{l}\text { Unidimensional } \\
\text { concept }\end{array}$ & (1) CSR & $\begin{array}{l}\text { Lichtenstein et al. (2004); Podnar and Golob (2007); } \\
\text { Marín and Ruiz (2007) }\end{array}$ \\
\hline $\begin{array}{l}\text { Carroll's CSR } \\
\text { pyramid }\end{array}$ & $\begin{array}{l}\text { (1) Economic } \\
\text { (2) Legal } \\
\text { (3) Ethical } \\
\text { (4) Philanthropic }\end{array}$ & $\begin{array}{l}\text { Carroll (1979); Aupperle et al. (1985); Wartick and } \\
\text { Cochran (1985); Maignan et al. (1999); Maignan } \\
\text { (2001); Schwartz and Carroll (2003); García de los } \\
\text { Salmones et al. (2005) }\end{array}$ \\
\hline $\begin{array}{l}\text { Sustainable } \\
\text { development }\end{array}$ & $\begin{array}{l}\text { (1) Economic } \\
\text { (2) Environmental } \\
\text { (3) Social }\end{array}$ & $\begin{array}{l}\text { van Marrewijk (2003); Panapanaan et al. (2003); } \\
\text { Panwar et al. (2006) }\end{array}$ \\
\hline $\begin{array}{l}\text { Stakeholder } \\
\text { theory }\end{array}$ & $\begin{array}{l}\text { (1) Shareholders } \\
\text { (2) Customers } \\
\text { (3) Employees } \\
\text { (4) Society } \\
\text { (5) General }\end{array}$ & $\begin{array}{l}\text { Clarkson (1995); Maignan et al. (1999); Mercer } \\
\text { (2003); Decker (2004); Waldman et al. (2006); Turker } \\
\text { (2009) }\end{array}$ \\
\hline
\end{tabular}

Source: Compiled by author

Stakeholder theory has also been demonstrated to perfectly fit the banking industry approach to CSR (Soto 2006; Gorigolzarri 2006; Sarro et al. 2007; Ruiz et al. 2009). Ruiz et al. (2009) consider that sometimes banking institutions have just taken shareholders' interests into consideration leading to social problems such as the 
shortage of financing and financial exclusion. However, these authors believe that this situation has improved over the years with banks and building societies working to eradicate this problem in Spain. In this regard, Server and Capó (2009) consider that companies comply with their social responsibility when they incorporate their stakeholders' expectations into their strategic management. Furthermore, Sarro et al. (2007) believe that the implication of banking institutions in CSR initiatives is an answer to the commitment of these entities with society that goes far beyond the economic obligation to shareholders to also include responsibilities towards other stakeholders such as employees, customers, suppliers, the Government, investors or the local community. The most common stakeholders identified in the banking industry are shareholders, customers, employees and society (Gorigolzarri 2006).

All in all, the stakeholder perspective has begun to gain momentum in academic literature and appears to be the trend that CSR research will follow in the field of CSR in the near future (e.g. Boal and Peery 1985; Turker 2009). However, few studies have yet developed a scale based on stakeholder theory to measure CSR image (Mercer 2003). Furthermore, papers focusing on this issue have analyzed specific contexts and industries different from the banking sector (e.g. Mercer 2003; Turker 2009). Nevertheless, it is well known that CSR is contextual in nature (Decker 2004) so both its definition and dimensions depend on the specific characteristics of the companies in each industry as well as on the context in which all of them do business (Decker 2004). Therefore, a specific scale to measure CSR in the banking industry is still needed.

\section{Methodology}

\subsection{Scale development}

Following Turker's (2009) methodological proposal, based on a standard scale development process, a new multi-item scale is designed that includes items previously used in marketing literature regarding CSR.

First, the multidimensionality of the scale was conceptualized based on both a literature review and a qualitative exploratory research based on in-depth interviews with CSR and Reputation managers of some of the most important Spanish banks and building 
societies $^{1}$. In this regard, J.I. Goirigolzarri, former President of BBVA, defined four key stakeholders in the CSR policy of his bank: shareholders, customers, employees and society (Gorigolzarri 2006). Manuel Soto, fourth Santander vice-chairman, considers that a bank must acquire an ethical commitment to all stakeholders that are affected by corporate behaviour including shareholders, employees, customers, suppliers, governments and society (Soto 2006). Also along these lines, Sarro et al. (2007) identify six key stakeholders in the banking sector: customers, suppliers, employees, shareholders, society and the environment. These authors also consider that in the banking industry suppliers and customers could be considered as the same stakeholder since customers supply banking institutions with money, the essential input in this industry. Finally, Ruiz et al. (2009) consider that employees, customers and society are primary stakeholders in the banking industry while some secondary stakeholders such as regulators, the environment, the media or shareholders can also be identified. The qualitative study demonstrated that all the institutions analyzed use stakeholder theory to disclose their CSR policies in annual CSR reports and on the Internet. This research also revealed that, because of their legal status, building societies do not have shareholders although they still have to report to their supervising boards which evaluate their results and take decisions regarding the investments to be made.

After this first step, five dimensions were identified as relevant for the CSR image of a banking institution: customers, shareholders and supervising boards, employees, society and a general dimension concerning legal and ethical issues which include corporate responsibilities towards a broad array of stakeholders which, along with the ones already cited, also include governments or the media. In a second phase, items in each dimension were generated through a literature review. In this regard, CSR incorporates corporate behaviour committed to ethical practices, social projects or philanthropy, the environment and information transparency in corporate relationships with all stakeholders (Sarro et al. 2007).

First, items CSRImg1 to CSRImg5 refer to corporate activities oriented to customers, basically concerning complete and honest communication of corporate products and services and management of complaints. In this regard, Gorigolzarri (2006) considers

\footnotetext{
${ }^{1}$ Six CSR and Reputation managers of national banks and building societies were interviewed. The banks studied were Santander and BBVA and building societies were Caja Madrid, La Caixa, Caja Cantabria and Caja Navarra.
} 
that corporate relationships with customers should be based on three facts: information transparency, self-discipline and the development of new products and services. The proposed items cover these three issues. Sarro et al. (2007) also consider that CSR towards customers includes all initiatives undertaken to provide the highest quality in products and the most competitive prices, which implies analyzing customers' needs and measuring their satisfaction. All the items were taken from previous papers by Maignan et al. (1999) -CSRImg1, CSRImg3 and CSRImg4-, García de los Salmones et al. (2005) -CSRImg2- and Decker (2004) -CSRImg5.

Secondly, items CSRImg6 to CSRImg9 are related to corporate responsibilities towards shareholders (in the case of banks), and supervising boards (in the case of building societies). These items are especially oriented to the evaluation of corporate profitability -CSRImg6 to CSRImg8- and information transparency -CSRImg9- since these are considered the main responsibilities of institutions towards these stakeholders in the banking industry (Sarro et al. 2007). Soto (2006) believes that the first responsibility of an organization is to be profitable especially in the current competitive market and that, in doing so, companies demonstrate that they are doing both well. Goirigolzarri (2006) also thinks that being profitable derives in wealth creation for society in the long run. Finally, Piñeiro et al. (2009) highlight that both investors and other stakeholders expect companies to comply with high transparency standards.

Items CSRImg10 to CSRImg14 were taken from Mercer (2003) and relate to responsibilities towards employees. These 5 items cover issues regarding job creation and employment opportunities which have been considered direct consequences of good CSR practices (Abad 2002). Also Goirigolzarri (2006) considers that employees' promotion should be based on equal opportunities and the fair evaluation and recognition of individual competences and performance. Sarro et al. (2007) point to career development, equal opportunities, training, conciliation and the offer of other social benefits as responsibilities of banking institutions towards their employees.

Furthermore, corporate obligations towards society are represented in items CSRImg15 to CSRImg20 and refer to issues such as charity, community development or environmental protection. In this regard, Sarro et al. (2007) identify diverse corporate responsibilities towards society such as the advancement of underpriviledged groups or 
corporate contribution to solve social problems such as financial exclusion. These issues are evaluated in items CSRImg15 to CSRImg19. Finally CSRImg20 refers to environmental protection (Sarro et al. 2007). Even though some authors consider the environment as a differentiated dimension of CSR, we had included it as part of society because of its lack of personal character which prevents it from being considered as a stakeholder itself.

Finally, items CSRImg21 to CSRImg23 include ethical and legal concerns which refer to general corporate responsibilities that do not benefit specific stakeholders but benefit all of them to the same extent. This dimension had already been tested and confirmed by Maignan et al (1999). So, items were taken from previous papers by this Dutch author (Maignan et al. 1999; Maignan 2001).

\subsection{Research design and sample}

To test the adequacy of this new CSR image scale a quantitative study based on personal surveys of Spanish customers of banking services wass designed. The researchers applied interviewer-administered questionnaires which were completed in familiar places for the interviewees (home, parks or cafés, among others). The purpose of this methodology was to allow customers to feel comfortable when giving their answers as well as to assure that interviewees were fully concentrating on the survey and had no other assignments which could interfere in the reliability and validity of their responses.

To design the research sample a multi-stage sampling by quotas was used based on the characteristics of the population derived from two relevant research criteria: the interviewee's gender and age (Census Bureau 2009). The sample representativity can be checked in Table 2 where descriptive information about the population in the universe and sample is presented.

TABLE 2

Profile of the population and the sample

\begin{tabular}{ccccc}
\hline \hline \multirow{2}{*}{ Variable } & \multicolumn{2}{c}{ Spain Population } & \multicolumn{2}{c}{ Sample } \\
& $\mathbf{N}$ & $\%$ & $\mathbf{N}$ & $\%$ \\
\hline \hline
\end{tabular}

Gender: 


\begin{tabular}{lcccc}
\hline \hline Male & 18.903 .405 & 49,03 & 547 & 48,67 \\
Female & 19.650 .236 & 50,97 & 577 & 51,33 \\
& $\mathbf{3 8 . 5 5 3 . 6 4 1}$ & $\mathbf{1 0 0}$ & $\mathbf{1 1 2 4}$ & $\mathbf{1 0 0}$ \\
Age (years): & & & & \\
Under 44 & 19.329 .243 & 50,14 & 523 & 46,54 \\
Between 45 and 64 & 11.441 .494 & 29,68 & 362 & 32,2 \\
Over 64 & 7.782 .904 & 20,19 & 239 & 21,26 \\
& $\mathbf{3 8 . 5 5 3 . 6 4 1}$ & $\mathbf{1 0 0}$ & $\mathbf{1 1 2 4}$ & $\mathbf{1 0 0}$ \\
Education ${ }^{2}$ : & & & & \\
No education & & 15,33 & 46 & 4,09 \\
Elementary & n.d & 23,08 & 219 & 19,48 \\
High School & & 48,04 & 448 & 39,86 \\
College & & 13,55 & 411 & 36,57 \\
& & $\mathbf{1 0 0}$ & $\mathbf{1 1 2 4}$ & $\mathbf{1 0 0}$ \\
Occupation: & & & & \\
Employed & & 53,55 & 632 & 56,22 \\
Unemployed & & 6,85 & 50 & 4,45 \\
Student & n.d. & 5,88 & 121 & 10,77 \\
Housewife & & 12,54 & 94 & 8,36 \\
Retired & & 21,18 & 227 & 20,20 \\
& & $\mathbf{1 0 0}$ & $\mathbf{1 1 2 4}$ & $\mathbf{1 0 0}$ \\
\hline \hline
\end{tabular}

The field work was performed in April 2010, and after the collection and processing of the information, a total of 1124 valid surveys remained. As two significantly different banking institutions are identified in the Spanish market, the sample is divided into banks' and building societies' customers and the validation of the scale is independently undertaken in both samples. 476 surveys were gathered for banks' customers and 648 surveys for building societies' customers.

\section{Results}

\subsection{Exploratory factor analysis}

In order to test the adequacy of this new scale, first an Exploratory Factor Analysis is carried out in each sample. Varimax rotation is used, which results in the identification of five dimensions that account for $66.21 \%$ of the total variance in the banks sample and $67.30 \%$ in the building societies sample. Thus, the validity of the five theoretical dimensions is demonstrated. However, when analyzing factor loadings for all items, it is observed that CSRImg9, referring to how the company "honestly informs about its economic situation to its shareholders and/or supervising boards", is under 0.4 , the minimum value suggested by Hair et al. (2010) -0.384 for banks and 0.379 for building

\footnotetext{
${ }^{2}$ Population in family homes, 16 years or older. Last data available from the 2001 Population Census, updated in 2004.
} 


\subsection{Scale validation}

In the second validation step the psychometric properties of the scale -reliability and validity- are evaluated. For this purpose, both first- and second-order confirmatory factor analyses (CFA) are performed according to the maximum robust likelihood estimation procedure, using the statistical software program EQS 6.1. The reliability of the proposed measurement scale is evaluated using Cronbach's alpha $(\alpha)$ and the Average Variance Extracted -AVE-. The values of these statistical parameters are above or near the minimum recommended values of 0.7 and 0.5 in both samples (Hair et al. 2010), thus confirming the internal reliability of the proposed construct. In addition, all the items are significant to a confidence level of $95 \%$ and their standardised lambda coefficients are greater than 0.5 (Steenkamp and van Trijp 1991), which confirms the convergent validity of the model. We used the process described by Anderson and Gerbing (1988) to verify the discriminant validity and the confidence intervals for the correlation of the constructs are obtained and compared with the unity. None of the intervals contain this value, thus confirming that the proposed measurement model is correct. Finally, the goodness-of-fit of the analysis is measured with the Chi-square statistic (Satorra-Bentler) and the Comparative Fit Indexes -NFI, NNFI, CFI and IFIas they are the most common measures in CFA and SEM. Although the Chi-square is significant in both samples $(\mathrm{p}<0.05)$, this result can be a consequence of the large size of the samples -over 200 cases- (Hair et al. 2010). So, we completed the analyses with the Comparative Fit Indexes which are in all cases close to or above 0.9 (Bentler 1992), thus confirming the good fit of the model to the data collected. 
TABLE 4

First-order CFA of the CSR image

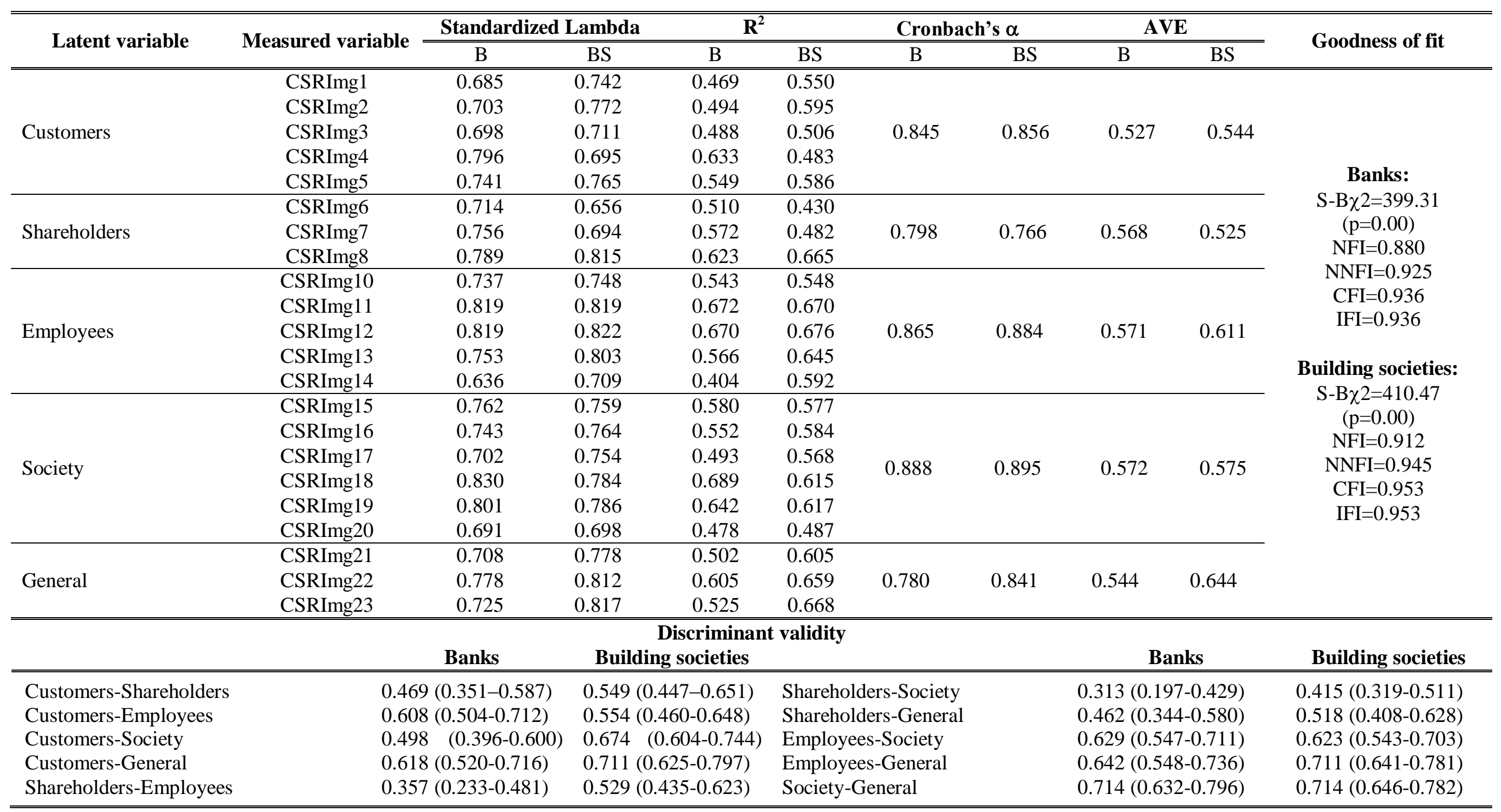


Finally, the many dimensions of CSR are tested with a second-order confirmatory analysis, and the results are shown in Figure 1. Once again, the values of the Chi-square are significant but the comparative fit indexes confirm the validity of the proposed scale.

FIGURE 1

Second-order CFA of the CSR image

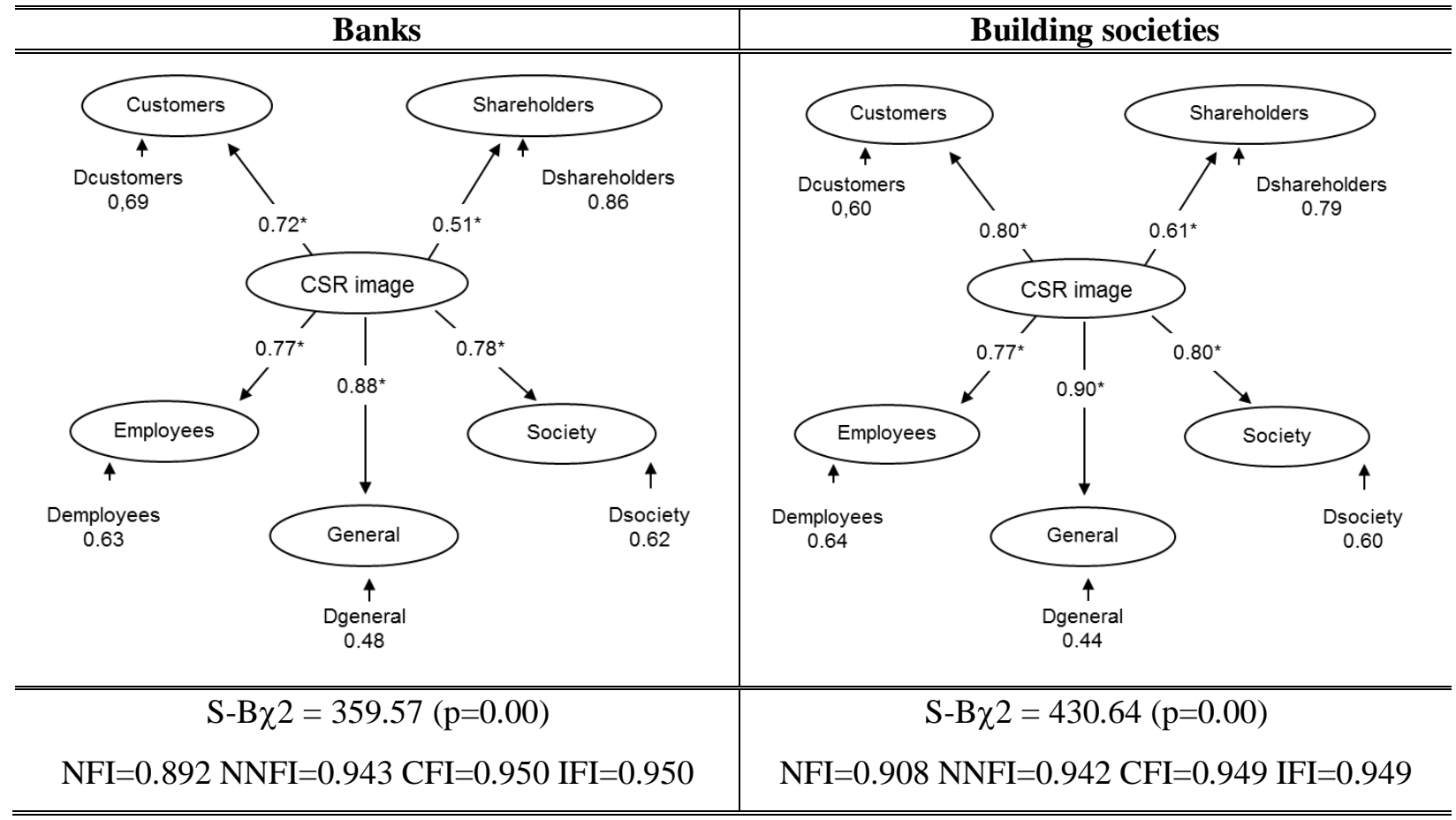

According to these analyses, the first relevant result is that the users of banking services perceive CSR as the collection of corporate actions as they relate to customers, shareholders, employees, society and a general dimension that gathers ethical and legal aspects that pertain to all stakeholders. This result is confirmed in two different samples evaluating CSR of banking institutions with traditionally different approaches to CSR. So, the reliability and validity of the measurement tool proposed for CSR image in the banking industry is well supported in this research.

Another relevant result is the elimination of one of the items in the scale. Item CSRImg9 referred to corporate information transparency and honesty when informing "about its economic situation to its shareholders and/or supervising boards" but it dropped from the analysis in the first step of the validation. This result might be a 
consequence of certain lack of information regarding this issue which could have led customers to underestimate the item. Finally, a 22-item scale based on stakeholder theory is confirmed for the measurement of CSR in the banking industry.

\subsection{Descriptive statistics}

Taking this CSR image scale as a reference, customers' perceptions of CSR performance on each image dimension are analyzed. First, it is observed that those items better valued by bank customers are those related to the insurance of corporate survival and long term success (Mean ${ }_{\text {CSRImg } 8}=5.87$ ), the maximization of corporate profits (Mean CSRImg6 $=5.72$ ), the respect towards rules and regulations defined by law $\left(\right.$ Mean $\left._{\mathrm{CSRImg} 21}=5.58\right)$ and the honest relationship with customers $\left(\right.$ Mean $\left._{\mathrm{CSRImg} 2}=5.53\right)$. At the same time, the least rated items in this sample relate to corporate initiatives in favour of society: respecting and protecting the natural environment (Mean $\operatorname{CSRImg20}_{2}=4.57$ ), using part of its budget for donation and social projects $\left(\right.$ Mean $_{\mathrm{CSRImg} 16}=4.68$ ), being concerned with improving the general well-being of society (Mean CSRImg19=4.72),

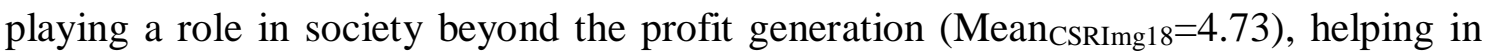
solving social problems (Mean ${ }_{\text {CSRImg15 }}=4.74$ ) and contributing money to cultural and social events (Mean ${ }_{\text {CSRImg17 }}=4.88$ ). Thus, it can be seen that issues especially related to economic, legal and customer matters are better perceived by bank customers. Thus, 'shareholders and supervising boards', 'general' and 'customers' are salient dimensions. On the other hand, items more concerned with employees receive mild evaluations while 'society' is a poorly evaluated CSR dimension.

Two facts explain these results. First, the current economic crisis situation, derived from land speculation in Spain and all the financial scandals during the 90s and early 00s, have taken banks to care particularly for legal and economic issues. As a result, banks have tried to improve their public image and reputation by especially focusing on these two CSR dimensions, significantly affecting their business. Second, banks have traditionally been private companies with a strong commercial orientation in highly competitive markets. As already explained in the second section of this paper, competitition and the lack of differentiation have led companies to work in relationship marketing strategies to keep customers satisfied and loyal. 
On the other hand, CSR image results for building societies show that no stakeholder stands out in their CSR policies. The best evaluated items relate to the general dimension of CSR (Mean CSRImg21 $_{1}=5.57$ ), supervising boards (Mean ${ }_{\text {CSRImg } 8}=5.52$ ), employees $\quad\left(\left(\right.\right.$ Mean $_{\mathrm{CSRImg} 12}=5.52 ; \quad$ Mean $\left._{\mathrm{CSRImg} 11}=5.42\right) \quad$ and customers (Mean ${ }_{\text {CSRImg2 }}=5.40$ ). Among the worst evaluated items again we find social issues $\left(\right.$ Mean $_{\text {CSRImg20 }}=4.69 ;$ Mean $_{\text {CSRImg18 }}=5.00 ;$ Mean $\left._{\text {CSRImg19 }}=5.04\right)$ and customer initiatives $\left(\right.$ Mean $_{\text {CSRImg5 }}=4.75 ;$ Mean $_{\text {CSRImg4 }}=4.82$ ). Thus, in building societies CSR perceptions seem to be more balanced among stakeholders, which is a direct consequence of the broader perspective that these institutions have always tried to give to their CSR policies. Nevertheless, it is also noteworthy that building societies have always tried to base their positioning in the market on their strong social commitment, represented in their foundations for social projects. However, it is observed that this CSR dimension seems to be one of the most poorly evaluated ones, just as happens in the bank sample, when these institutions have not made such an effort to communicate their social commitment.

\section{TABLE 5}

Perception of the performance of banking service institutions on each of the items of CSR image

\begin{tabular}{lrlr}
\hline \hline \multicolumn{4}{c}{ Banks } \\
\multicolumn{1}{c}{ Ident. } & Mean & \multicolumn{1}{c}{ Ident. } & Mean \\
\hline \hline CSRImg8 & 5,87 & CSRImg14 & 5,17 \\
CSRImg6 & 5,72 & CSRImg23 & 5,16 \\
CSRImg21 & 5,58 & CSRImg10 & 5,13 \\
CSRImg2 & 5,53 & CSRImg4 & 5,07 \\
CSRImg7 & 5,50 & CSRImg5 & 4,94 \\
CSRImg22 & 5,45 & CSRImg17 & 4,88 \\
CSRImg3 & 5,42 & CSRImg15 & 4,74 \\
CSRImg1 & 5,41 & CSRImg18 & 4,73 \\
CSRImg12 & 5,39 & CSRImg19 & 4,72 \\
CSRImg11 & 5,35 & CSRImg16 & 4,68 \\
CSRImg13 & 5,26 & CSRImg20 & 4,53 \\
\hline \hline
\end{tabular}

\begin{tabular}{lrlr}
\hline \hline \multicolumn{4}{c}{ Building societies } \\
\multicolumn{1}{c}{ Ident. } & Mean & \multicolumn{1}{c}{ Ident. } & Mean \\
\hline \hline CSRImg21 & 5,57 & CSRImg10 & 5,23 \\
CSRImg8 & 5,52 & CSRImg7 & 5,22 \\
CSRImg12 & 5,52 & CSRImg16 & 5,20 \\
CSRImg6 & 5,43 & CSRImg23 & 5,20 \\
CSRImg11 & 5,42 & CSRImg13 & 5,15 \\
CSRImg2 & 5,40 & CSRImg15 & 5,14 \\
CSRImg22 & 5,39 & CSRImg19 & 5,04 \\
CSRImg17 & 5,34 & CSRImg18 & 5,00 \\
CSRImg3 & 5,30 & CSRImg4 & 4,82 \\
CSRImg14 & 5,27 & CSRImg5 & 4,75 \\
CSRImg1 & 5,23 & CSRImg20 & 4,69 \\
\hline \hline
\end{tabular}

To reliably confirm the differences intuitively perceived in this table, a comparison of differences between means is carried out for CSR image dimensions both in the banks and building societies samples. The analyses suggest that there are significant differences in the valuation given by customers to each of the dimensions of CSR image 
both for banks and building societies ( $\mathrm{p}=0.00$ for all comparisons). Thus, a hierarchy in corporate performance can be established from the evaluation of the different CSR dimensions, which indicates that the customers in the bank sample have an especially positive perception of corporate CSR initiatives that favour shareholders. Roughly speaking, these issues are strongly linked to economic aspects. Customers also positively evaluate the ethical and legal actions that are classified in the general dimension of CSR. The perception of corporate actions that are closely linked to benefits for customers, employees and society are notably inferior. For building societies a quite similar hierarchy also exists, although quantitative differences among dimensions are less strong in this sample. In this case, customers evaluate CSR initiatives as follows: supervising boards, general dimension, employees, customers and society. Thus, previous descriptive results are confirmed.

Finally, an interesting result derives from the comparison of banks' and building societies' evaluations. For this purpose, a comparison between means for independent samples was carried out in PASW v.18.0. Results are shown in table 6. In this regard, customers understand that both kinds of banking institutions are working quite similarly in CSR dimensions related to ethical and legal issues and employees' initiatives ( $p>0.05)$. These results can be a consequence of the normative character of most of the CSR initiatives evaluated in these dimensions which have been progressively included in banking regulations over the last decades. Some significant differences still exist when comparing customers, shareholders and supervising boards and the society dimensions which derive from the different traditional approach to CSR of banks and building societies.

TABLE 6

Differences between means for CSR image dimensions

\begin{tabular}{cccccc}
\hline \hline \multirow{2}{*}{ Dimension } & \multicolumn{2}{c}{ Mean } & \multicolumn{3}{c}{ Differences between means } \\
& B & BS & Mean & Std. deviation & Signification \\
\hline \hline Customers & 5.276 & 5.104 & .172 & .0635 & 0.007 \\
\hline Shareholders & 5.699 & 5.388 & .310 & .069 & 0.000 \\
\hline Employees & 5.254 & 5.316 & -.062 & .063 & 0.327 \\
\hline Society & 4.718 & 5.065 & -.347 & .070 & 0.000 \\
\hline General & 5.402 & 5.384 & .018 & .066 & 0.783 \\
\hline \hline
\end{tabular}




\section{Discussion}

A detailed review of academic literature shows that the identification of rigorous and complete measures of CSR image is a complicated task (Turker 2009). Nevertheless, a very common trend nowadays takes stakeholder theory as a reference to propose diverse dimensions of corporate responsibilities oriented towards each of the company's targets (Clarkson 1995; Mercer 2003; Decker 2004; Turker 2009). However, this research venue is quite new and there are still few studies testing reliable scales to measure CSR image. Furthermore, the application of CSR principles to corporate activities is dependent on corporate and industrial contextual characteristics, so the systematic development of measures adapted to specific sectorial features is essential to understand better the role of CSR in customers' thoughts and behaviour. In this paper the authors design a new reliable tool to measure CSR image in the banking sector, testing its validity for different kinds of banking institutions and taking customers as the stakeholder of reference.

The first outstanding result is the confirmation of the multidimensionality of CSR image. This result is congruent with previous studies, even though some of them were based on different theoretical frameworks (Maignan et al. 1999; Maignan 2001; Mercer

2003; Decker 2004; García de los Salmones et al. 2005; Kim and Choi 2007). Contrary to classical propositions that consider CSR as the collection of economic, legal, ethical and philanthropic corporate responsibilities, the scale tested in this paper divides CSR image according to the stakeholders who are considered to take advantage of CSR activities. CSR image is then divided into 5 dimensions: customers, shareholders and supervising boards, employees, society and one general dimension including all legal and ethical responsibilities which are oriented to satisfy all stakeholders equally. By designing this scale, the authors have contributed to CSR knowledge since most academic proposals regarding CSR have been developed at a theoretical level while few papers have empirically analyzed specific stakeholders' perceptions.

Secondly, customers' evaluations of the performance of their banking service providers on each CSR dimension must also be highlighted. Some interesting results have been identified since it has been observed that banks' and building societies' customers do 
not have the same CSR perception in both kinds of institutions. The most highly rated dimensions in banks are those related to corporate obligations towards sahoreholders, legal responsibilities - general dimension- and customers. Corporate CSR activities oriented to the enhancement of the society are more poorly evaluated. These results can be easily understood if the current financial crisis and banks' commercial orientation are considered. These companies are focused on attracting money through customers' savings while financing investments. These two activities are closely linked to the most economic concerns of any commercial activity. Thus, these three stakeholders are to banks what Mitchell et al. (1997) defines as definitive stakeholders. On the contrary, building societies' CSR policies are perceived as better balanced and fewer critical differences among stakeholders are perceived. These results confirm previous findings in the banking industry where de la Cuesta et al. (2006) already identified significant differences in the development of CSR information and communication between banks and building societies.

Furthermore, when analyzing more deeply the dimensions concerning customers and society, it is possible to identify some interesting issues to be improved, and some managerial implications can be derived. First, activities especially committed to the enhancement of societal issues, such as caring for the environment, working to improve the welfare of local communities or the representation of a role in society broader than the pursuit of an economic goal, are some of the least salient issues for customers. Thus, more effective corporate strategies regarding these activities should be designed. This result is particularly significant for building societies since they have traditionally positioned themselves based on their social projects and foundations. These are timely findings which highlight the necessity of a revision in these CSR policies now that building societies are going through a restructuring process and have to redefine their strategic plans (Pérez and Rodríguez del Bosque 2011).

On the other hand, activities oriented to satisfying customers were not well evaluated in building societies either. Corporate responsibilities such as working to understand customers' needs or the rating of customer satisfaction as an indicator to improve customer service were poorly rated. These results have direct implications for CSR and Reputation managers since it has been demonstrated that customers care particularly about all corporate concerns that most directly benefit these stakeholders (Mercer 2003). 
These ideas should motivate companies to strengthen their bonds with customers in order for the latter to be less sensitive to market changes and competitive strategies.

Finally, some research limitations should be admitted. First, despite the fact that the scale presented represents balanced consideration of stakeholders and is a reliable tool to measure CSR image in the banking sector, it is necessary to highlight that not all possible corporate stakeholders were included in the analysis. As theoretically explained in the literature review, the most cited stakeholders were considered. However, some previous studies have demonstrated that additional targets, such as suppliers and governments, could be included in future research proposals analyzing other contexts (Turker 2009). Second, the design of this research did not allow the gathering of longitudinal information. So, plausible variations in customers' perception derived from the international financial crisis could not be registered. For example, a significant issue that has arisen in the current financial crisis relates to the rationing of the credit extended to users and financial exclusion. However, we designed our scale based on papers and scales proposed in positive phases of the business cycle and overlooked this issue, which should be included for a more realistic picture of the current situation. Accordingly, new research in different contexts and temporal frames would contribute to generating a better knowledge of the CSR concept.

\section{References}

Abad F (2002) Ocho claves de la acción social empresarial en España. Harvard Deusto Marketing y Ventas 51: 46-51.

Anderson J, Gerbing D (1988) Structural Equation Modelling in Practice: A Review and Recommended Two-Step Approach. Psychological Bulletin 103(3): 411-423.

Aupperle KE, Carroll AB, Hatfield JD (1985) An Empirical Examination of the Relationship Between Corporate Social Responsibility and Profitability. Academy of Management Journal 28(2): 446- 463.

Bentler PM (1992) On the Fit of Models to Covariances and Methodology to the Bulletin. Psychological Bulletin 112: 400-404.

Boal KB, Peery N (1985) The Cognitive Structure of Corporate Social Responsibility. Journal of Management 11(3):71-83. 
Bravo R, Matute J, Pina, J (2011) Corporate social responsibility as a vehicle to reveal the corporate identity: A study focused on the websites of Spanish financial entities. Journal of Business Ethics. Available on-line: http://www.springerlink.com/content/4312187g5v33k783/

Carnero F, Nuez JS, Barroso C (2010) Banca Cívica. Reinventando la obra social de las cajas de ahorros. CIRIEC-España, Revista de Economía Pública, Social y Cooperativa 68: 203-222.

Carroll AB (1979) A Three-Dimensional Conceptual Model of Corporate Performance. The Academy of Management Review 184: 497-505.

CECA (2008) Libro verde de la responsabilidad social corporativa en el sector financiero. Conferencia Española de Cajas de Ahorro.

Census Bureau (2009). URL: http://www.ine.es

Clarkson MBE (1995) A Stakeholder Framework for Analyzing and Evaluating Corporate Social Performance. Academy of Management Review 20(1): 92-117.

Decker OS (2004) Corporate social responsibility and structural change in financial services. Managerial Auditing Journal 19(6): 712-728.

de la Cuesta M, Muñoz MJ, Fernández MA (2006) Analysis of Social Performance in the Spanish Financial Industry Through Public Data. A Proposal. Journal of Business Ethics 69:289-304.

Flavián C, Guinalíu M, Torres E (2005) The Influence of Corporate Image on Consumer Trust: A Comparative Analysis in Traditional Versus Internet Banking. Internet Research 15(4): 447-470.

Freeman RE (1984) Strategic Management: A Stakeholder Approach. Pittman, Boston, MA.

García de los Salmones MM, Herrero A, Rodríguez del Bosque I (2005) Influence of Corporate Social Responsibility on Loyalty and Valuation of Services. Journal of Business Ethics 61:369-385.

Goirigolzarri JI (2006). La responsabilidad social en el sector financiero: el BBVA. Working paper, Fundación Carolina.

Hair JF, Black WC, Babin BJ, Anderson RE (2010) Multivariate Data Analysis (7 ed) Pearson Prentice-Hall, Upper Saddle River, NJ.

Jamrozy U (2007) Marketing of tourism: a paradigm shift toward sustainability. International Journal of Culture, Tourism and Hospitality Research 1(2): 117-130. 
Kim SW, Choi CJ (2007) Habits, self-control and social conventions: The role of global media and corporations. Journal of Business Ethics 76(2): 147-154.

KPMG (2008) KPMG International Survey of Corporate Responsibility Reporting 2008. URL: http://www.kpmg.es.

Lichtenstein D, Drumwright M, Braig B (2004) The Effect of Corporate Social Responsibility on Customer Donations to Corporate-Supported Nonprofits. Journal of Marketing 68: 16-32.

Maignan I (2001) Consumers' Perceptions of Corporate Social Responsibilities: A Cross-Cultural Comparison. Journal of Business Ethics 30: 57-72.

Maignan I, Ferrell OC, Hult GT (1999) Corporate Citizenship: Cultural Antecedents and Business Benefits. Journal of the Academy of Marketing Science 27(4): 455-469.

Mandell L, Lachman R, Orgler Y (1981) Interpreting the Image of Banking. Journal of Bank Research summer: 96-104.

Marín L, Ruiz S (2007) I Need You Too! Corporate Identity Attractiveness for Consumers and the Role of Social Responsibility. Journal of Business Ethics 71: 245260.

Mercer JJ (2003) Corporate Social Responsibility and Its Importance to Consumers. Tesis Doctoral. Claremont Graduate University.

Mitchell RK, Agle BR, Wood DI (1997) Toward a theory of stakeholder identification and salience: Defining the principle of who and what really counts. Academy of Management Review 22(4): 853-886.

Panapanaan VM, Linnanen L, Karvonen M, Phan VT (2003) Roadmapping Corporate Social Responsibility in Finnish Companies. Journal of Business Ethics 44(2/3): 133148.

Panwar R, Rinne T, Hansen E, Juslin H (2006): Corporate Responsibility: Balancing Economic, Environmental, and Social Issues in the Forest Products Industry. Forest Products Journal 56(2): 4-12.

Peñas MJ (2011) La privatización de las cajas de ahorros y el papel de la Comisión de Obra Social.CIRIEC-España, Revista de Economía Pública, Social y Cooperativa 70: 209-226.

Pérez A, Rodríguez del Bosque I (2011): The role of CSR in the corporate identity of banking service providers. Journal of Business Ethics. Available on-line: http://www.springerlink.com/content/f2031874707q0864/ 
Piñeiro J, Romero N, Vizcaíno M (2009) Riesgo de reputación y responsabilidad social empresarial en el sector financiero. La inversión socialmente responsable. Ecosostenible, 57: 4-16.

Podnar K, Golob U (2007) CSR Expectations: The Focus of Corporate Marketing. Corporate Communications: An International Journal 12(4): 326-340.

Poolthong Y, Mandhachitara R (2009) Customer Expectations of CSR, Perceived Service Quality and Brand Effect in Thai Retail Banking. International Journal of Bank Marketing 27(6): 408-427.

Rugimbana R, Quazi A, Keating B (2008) Applying a Consumer Perceptual Measure of Corporate Social Responsibility: A Regional Australian Perspective. The Journal of Corporate Citizenship 29: 61-74.

Ruiz M, de los Ríos A, Tirado P (2009) La responsabilidad social y la crisis económica. ¿Responden las entidades financieras españolas a los grupos de interés?. CIRIECEspaña, Revista de Economía Pública, Social y Cooperativa 65: 33-58.

Sarro MM, Cuesta P, Penelas A (2007) La responsabilidad social corporativa (RSC): una orientación emergente en la gestión de las entidades bancarias españolas. In Ayala JC (2007), Conocimiento, Innovación y emprendedores: camino al futuro. Universidad de La Rioja.

Schwartz MS, Carroll AB (2003) Corporate Social Responsibility: A Three-Domain Approach. Business Ethics Quarterly 13(4): 503-530.

Selvi Y; Wagner E; Turiel A (2010) Corporate Social Responsibility in the time of financial crisis: Evidence from Turkey. Annales Universitatis Apulensis Series Oeconomica 12(1): 281-290.

Server RJ, Capó J (2009) La Responsabilidad Social Empresarial en un context de crisis. Repercusión en las Sociedades Cooperativas. CIRIEC-España, Revista de Economía Pública, Social y Cooperativa 65: 7-31.

Soto M (2006). La responsabilidad social en el sector financiero: el Grupo SCH. Working paper, Fundación Carolina.

Steenkamp J, Van Trijp H (1991) The Use of LISREL in Validating Marketing Constructs. International Journal of Research in Marketing 8: 283-299.

Timur S, Getz D (2009) Sustainable Tourism Development: How Do Destination Stakeholders Perceive Sustainable Urban Tourism. Sustainable Development 17: 220232. 
Truscott RA, Bartlett JL, Tywoniak SA (2009) The reputation of the corporate social responsibility industry in Australia. Australasian Marketing Journal 17(2): 84-91.

Turker D (2009) Measuring Corporate Social Responsibility: A Scale Development Study. Journal of Business Research 85: 411-427.

van Marrewijk M (2003) Concepts and Definitions of CSR and Corporate Sustainability: Between Agency and Communion. Journal of Business Ethics 44(2-3): 95-105.

Wartick SL, Cochran PL (1985) The Evolution of the Corporate Social Performance Model. Academy of Management Review 10: 758-769.

\section{Appendix}

\section{Measurement scale for CSR image}

\begin{tabular}{|c|c|}
\hline Ident. & References \\
\hline I believe that this company $(X) \ldots$ & \\
\hline CSRImg1.Establishes procedures to comply with customers' complaints & \multirow{5}{*}{$\begin{array}{l}\text { Maignan et al. (1999); } \\
\text { Mercer (2003); García de } \\
\text { los Salmones et al. (2005) }\end{array}$} \\
\hline CSRImg2.Treats its customers honestly & \\
\hline $\begin{array}{l}\text { CSRImg3. Has employees that offer complete information about corporate } \\
\text { products/services to customers }\end{array}$ & \\
\hline $\begin{array}{l}\text { CSRImg4.Uses customers' satisfaction as an indicator to improve the } \\
\text { product/service marketing }\end{array}$ & \\
\hline CSRImg5.Make an effort to know customers' needs & \\
\hline CSRImg6.Tries to maximize its profits & \multirow{4}{*}{$\begin{array}{l}\text { Maignan et al. (1999); } \\
\text { Maignan (2001); Mercer } \\
\text { (2003); García de los } \\
\text { Salmones et al. (2005) }\end{array}$} \\
\hline CSRImg7.Keep a strict control over its costs & \\
\hline CSRImg8.Tries to insure its survival and long-term success & \\
\hline $\begin{array}{l}\text { CSRImg9.Honestly informs about its economic situation to its shareholders } \\
\text { and/or supervising boards }\end{array}$ & \\
\hline CSRImg10.Pay fair salaries to its employees & \multirow{5}{*}{$\begin{array}{l}\text { Boal and Peery (1986); } \\
\text { Maignan et al. (1999); } \\
\text { Mercer (2003) }\end{array}$} \\
\hline CSRImg11.Offer safety at work to its employees & \\
\hline CSRImg12.Treats its employees fairly (without discrimination or abuses) & \\
\hline CSRImg13.Offers training and career opportunities to its employees & \\
\hline $\begin{array}{l}\text { CSRImg14.Offers a pleasant work environment (e.g. flexible hours, } \\
\text { conciliation) }\end{array}$ & \\
\hline CSRImg15.Helps solving social problems & \multirow{6}{*}{$\begin{array}{l}\text { Maignan et al. (1999); } \\
\text { Maignan (2001); García } \\
\text { de los Salmones et al. } \\
(2005)\end{array}$} \\
\hline $\begin{array}{l}\text { CSRImg16.Uses part of its budget for donations and social projects to } \\
\text { advance the situation of the most unprivileged groups of the society }\end{array}$ & \\
\hline $\begin{array}{l}\text { CSRImg17.Contributes money to cultural and social events (e.g., music, } \\
\text { sports) }\end{array}$ & \\
\hline $\begin{array}{l}\text { CSRImg18.Plays a role in the society beyond the economical benefits } \\
\text { generation }\end{array}$ & \\
\hline CSRImg19.Is concerned with improving the general well-being of society & \\
\hline $\begin{array}{l}\text { CSRImg20.Is concerned with respecting and protecting the natural } \\
\text { environment }\end{array}$ & \\
\hline CSRImg21.Always respects rules and regulations defined by law & \multirow{3}{*}{$\begin{array}{l}\text { Maignan et al. (1999); } \\
\text { Maignan (2001); Mercer } \\
\text { (2003); García de los } \\
\text { Salmones et al. (2005) }\end{array}$} \\
\hline $\begin{array}{l}\text { CSRImg22.Is concerned with fulfilling its obligations vis-à-vis its } \\
\text { shareholders, suppliers, distributors and other agents with whom it deals }\end{array}$ & \\
\hline CSRImg23.Is committed to well established ethic principles & \\
\hline
\end{tabular}

7-point Likert-scale (1=strongly disagree with the sentence; $7=$ strongly agree) 